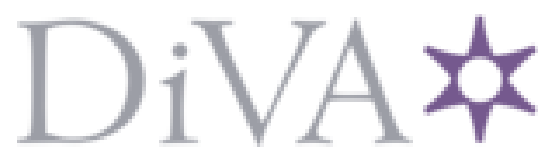

http://www.diva-portal.org

This is the published version of a paper published in Sport, Education and Society.

Citation for the original published paper (version of record):

Quennerstedt, M., Larsson, H. (2015)

Learning movement cultures in physical education practice.

Sport, Education and Society

http://dx.doi.org/10.1080/13573322.2014.994490

Access to the published version may require subscription.

N.B. When citing this work, cite the original published paper.

Permanent link to this version:

http://urn.kb.se/resolve?urn=urn:nbn:se:gih:diva-3722 


\title{
EDITORIAL
}

\section{Learning movement cultures in physical education practice}

\author{
Mikael Quennerstedt ${ }^{\mathrm{a} \star}$ and Håkan Larsson ${ }^{\mathrm{b}}$ \\ ${ }^{\mathrm{a}}$ School of Health and Medical Sciences, Örebro University, Örebro, Sweden; ${ }^{\mathrm{b}}$ The Swedish \\ School of Sport and Health Sciences (GIH), Stockholm, Sweden
}

\section{Introduction}

The focus of this special issue is how learning occurs in physical education (PE) practice in relation to different movement cultures in various contexts. The basis for the special issue is the Invited Symposium held at the AIESEP World Congress 2014 in Auckland, New Zealand, entitled Physical education - a subject for learning? The symposium revolved around learning in PE and the presenters, in line with a Swedish Didactics of Physical Education research tradition, were inspired by research in didactics and what in a wide sense can be called a sociocultural perspective of learning. In relation to learning, Wertsch $(1998$, p. 24$)$ states that: 'The task of a sociocultural approach is to explicate the relationship between human action, on the one hand, and the cultural, institutional and historical contexts in which action occurs on the other'.

Researchers from other countries were also involved in the special issue in order to attract and include scholars from a wider research community. The special issue accordingly aims to bring scholars from different countries together in order to explore learning in PE and what is considered as valuable knowledge in different movement cultures.

\section{Didactics - the study of learning, teaching and subject matter}

The articles included in this special issue can in a wide sense be regarded as research in didactics, learning and teaching (cf. Hudson \& Meyer, 2011). Didactics is a word that is commonly used in France, Germany and the Scandinavian countries and points to an interest in the relations between teaching, learning and socialisation. We are aware that in the English language the word didactics can mean systematic instruction, instrumental, instructive teaching methods or too much chalk-and-talk.

${ }^{\star}$ Corresponding author. School of Health and Medical Sciences, Örebro University, Örebro 701 82, Sweden. Email: mikael.quennerstedt@oru.se 
It is sometimes described as the art and science of teaching and occasionally translated as curriculum studies.

However, in many European countries, the concept stands for a research tradition with an interest in theories and practices of teaching and learning. In this sense, it has many similarities (but also some differences) with how the concept of pedagogy is used in research.

A central tenet for didactical research is that education involves many different choices in terms of content and form. These choices are made in classrooms, schools, politics and other areas of society. In didactical research, education and educational practices are explored and scrutinised in terms of their institutional and political prerequisites and their consequences for the processes of educational practice. Teaching is thus regarded as a political and moral act. More recently, the concept of didactics has been used in much the same way by English-speaking researchers, especially in the context of the European Educational Research Association network Didactics - Learning and Teaching.

The historical heritage of the concept of didactics (didaktik/didactique) is the classical work of Czech scholar and teacher educator John Amos Comenius, who already in 1657 wrote in his Didactica Magna (1657/1907):

Let the main object of this, our Didactic, be as follows: To seek and to find a method of instruction, by which teachers may teach less, but learners may learn more; by which schools may be the scene of less noise, aversion, and useless labour, but of more leisure, enjoyment, and solid progress (p. 4).

Besides writing extensively about teaching and instruction, Comenius also put teaching in relation to issues of learning and society at large. This interest has been captured in what is often related to as the didactic triangle, i.e. the relation between teacher, student and subject matter, and has lately been developed in terms of an expanded didactic triangle (Figure 1).

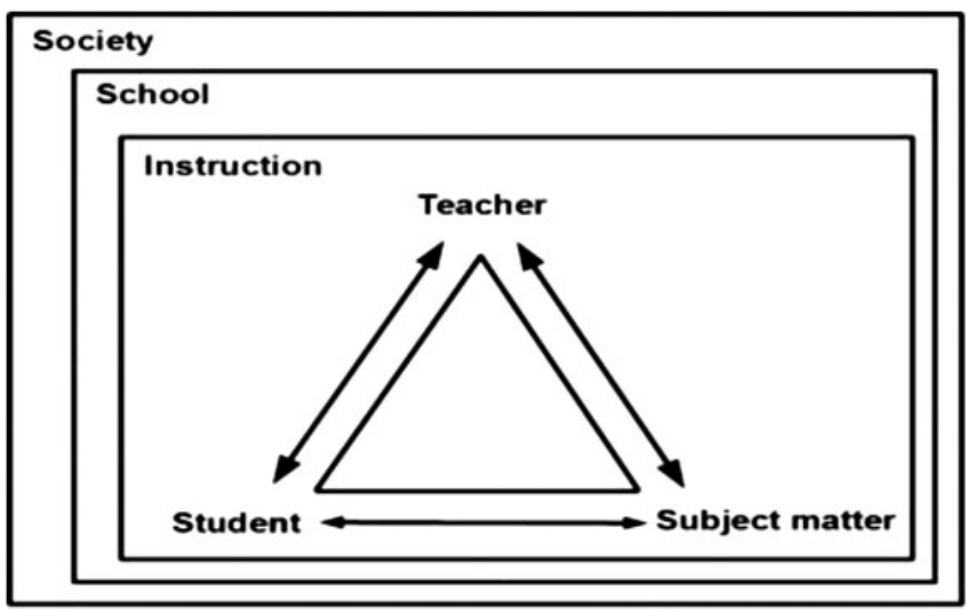

Figure 1. The expanded didactic triangle (Hudson \& Meyer, 2011, p. 8) 
Here it is clear that the research interests of didactics, learning and teaching share many of Wertsch's (1998) ideas about exploring learning socioculturally, as well as the interests of research within the field of PE around critical inquiry and critical pedagogy (cf. Enright, Hill, Sandford, \& Gard, 2014; Oliver \& Kirk, 2014; Stirrup \& Damant, 2014). However, sometimes research in didactics ask slightly different questions regarding educational practice, where didactical questions traditionally are addressed by the questions what, how and why, in terms of what and how teachers teach, what and how students learn and why this content or teaching is taught or learned. Questions such as who is teaching, who is learning, when and with whom are also relevant in this context.

These questions are of course not in themselves new within PE research. They have successfully over the years been explored within a situated learning theory tradition highlighting the context-embedded character of learning in relation to participation and membership in a social group (cf. Goodyear, Casey, \& Kirk, 2014; Kirk, 2012; MacPhail, Kirk, \& Kinchin, 2004). There are also links between a European tradition of didactics, teaching and learning, and sociocultural perspectives in PE, for example, using the work of Dewey, Bourdieu or Bernstein (cf. Andersson, Östman, \& Öhman, 2013; Cliff, 2012; Evans, Davies, \& Rich, 2009; Maivorsdotter \& Wickman, 2011; Strandbu \& Steen-Johnsen, 2014), and also research into pedagogical content knowledge and how teaching influences pedagogy (e.g. Ayvazo, Ward, \& Stuhr, 2010; McCaughtry, 2004; Rovegno, 1995).

Researchers within these traditions will hopefully recognise themselves in the articles in the special issue, and we rather see what we do as complementary to these important efforts. Hopefully, as Quennerstedt, Öhman, and Armour (2014) suggest, the articles of this special issue can contribute to a discussion regarding learning, so that the findings from studies of learning in PE could more easily be cumulative and that research findings across studies would have greater coherence.

\section{The cultural, institutional and historical contexts in which teaching and learning occur}

Researchers in didactics, teaching and learning are sometimes criticised for limiting their focus of study to a context restricted by the walls of the classroom or gym (cf. Quennerstedt et al., 2014). We agree that this has often been the case, but taking inspiration from scholars like Foucault, Bourdieu and Bernstein, we, in line with Wertsch (1998) and others, maintain that didactic research should always consider teaching and learning in its cultural, institutional and historical contexts.

Against this background, the special issue also takes its point of departure in Bart Crum's (1993, p. 341) notion of movement cultures as different movement activities and interactions, which 'refers to the way in which a social group deals with the need and desire for movement beyond labour or maintaining life'. In much the same way, Lars-Magnus Engström (2008) talks about the importance of analysing movement starting with the logic of practice. This should not be seen as a way of projecting a rational logic on practice (for instance, the function of any particular physical activity 
or movement, or the motive that people ascribe to how they move or which physical activity they participate in), but rather as a way of understanding practice on its own practical, historical and socially constituted terms.

Crum (1993) further argues that these cultures or practices occur across institutions such as schools, sports clubs, fitness centres and dance organisations to more informal spaces like school yards, parks, resorts and families. This special issue touches on how these different movement cultures become enacted and negotiated in different ways in different PE contexts.

\section{Didactical research-the case of Sweden}

But why research in didactics? In much the same way as in Norway, France, Tunisia (some of the contexts explored in this special issue) and other countries, in Sweden, research on education has traditionally been conducted within a strict national context. Some 10 or 15 years ago this also applied to research in Physical Education and Sport Pedagogy (PESP). However, since then, Swedish PESP researchers have made strong efforts to contextualise their research internationally. This endeavour has affected how researchers understand their research and the school subject of PE. In the early days, those of us researching PESP issues noticed that Swedish research and PE in schools had similarities and differences compared to other countries.

Regarding research, the differences include the relatively easy way for researchers in Sweden to gain access to schools (i.e. to undertake observational studies and make video recordings) and make contact with teachers and students (i.e. to conduct interviews). This is not always the case in other countries, for example, Australia or the UK (cf. Harcourt \& Quennerstedt, 2014), where the marketisation of schooling has increasingly made schools even more fearful of receiving negative publicity when participating in research. Although the Research Ethics Act in Sweden has been tightened up over the past decade, the school culture is still to a great extent characterised by the kind of relative openness that accompanied the highly centralised state-controlled school system of the 1960s and up to the 1990s.

In the countries explored in the papers of this special issue, $\mathrm{PE}$ as a school subject has many similarities with how it is taught in Australia, Brazil and the USA (cf. Pühse \& Gerber, 2005), where to some extent the curriculum content is dominated by different sports (Kirk, 2009). However, there are also differences, most commonly related to the norms, values and sociocultural framing of $\mathrm{PE}$, and in consequence the different movement cultures in each country.

In Sweden, for example, the relatively sceptical view of competitive sport that prevails among PE teachers in Sweden means that competitive sport is not formally supported (cf. Larsson \& Karlefors, 2015). There are further relatively few elements of explicit arguments in relation to what can be called an 'obesity discourse' (Evans, Rich, Davies, \& Allwood, 2008; Gard \& Wright, 2005). On the other hand, Swedish students seem to regard the subject of PE more positively than their counterparts in many other countries. When it comes to ideology and the purpose of having PE in schools, it seems as though the idea that the subject is 'something else' as compared 
to leisure time sport, and recreational physical activity is quite strong among both PE teachers and teacher educators. Although in practice the subject content is influenced by different sports and keep-fit activities, elements such as dance and outdoor life (friluftsliv) are also influential (Backman, 2008).

Of course, there are different ways of explaining why this situation has arisen in relation to learning movement cultures in PE practice. One is that the sceptical view of competitive sport and the view of PE as 'something different' are legacies from Per Henrik Ling, who not only founded Swedish gymnastics but also the Royal Central Gymnastics Institute in Stockholm, which for 150 years was the only PE teacher training institute in Sweden. According to historian Jens Ljunggren (2000), ideologically Ling was inspired by the continental tradition of Bildung. Bildung is still a central concept in Sweden, Norway and many other continental countries in debates about schooling (see e.g. Burman \& Sundgren, 2010; Hudson \& Meyer, 2011). In contemporary parlance, it is often framed in opposition to education (or training). In this frame, the aim of education is to provide the individual with vocational skills, whereas Bildung aims to transform the whole person. In relation to Crum's (1993) article about movement culture, Bildung can be equated with what Crum calls a 'pedagoglogistic ideology', where movement is seen as 'an outstanding medium for exploration, communication, personal development and character building' (p. 344f). However, according to Ljunggren, Bildung also includes a critical stance to civilisation, which had to make way for a more technocratic stance among the later Lingians, where the body was increasingly seen as a machine to be tuned to perfection.

Nevertheless, the critical approach that is common among Swedish PESP researchers, PE teachers and teacher educators is also present in research and in ways of reasoning about the subject and teacher education (cf. Larsson \& Redelius, 2008). This is most notable in the discussion about the expanded didactic triangle, where PE and PE teaching are never seen to occur in a void but are inscribed in a social context. Indeed, from the point of view of PE, we argue that Bildung is not only about transforming the person but also about transforming society. In our didactical research, we, together with critical researchers from many other countries, continuously ask how societal issues affect PE teaching and what PE has to offer society, at least in terms of research and schooling.

Here, using the case of Sweden as an example of how cultural, institutional and historical contexts of PE can create different conditions for teaching and learning, the authors of the special issue hope to contribute to a critical and constructive discussion about didactics, teaching, pedagogy, assessment and student learning in $\mathrm{PE}$ in relation to movement cultures in a wide sense.

\section{Content of the special issue}

In this special issue, researchers from Australia, France, Ireland, Norway, Sweden, Tunisia and the UK come together and discuss learning movement cultures in PE practice. 
In the first paper, Håkan Larsson and Inger Karlefors (2015) explore how movement cultures condition teaching and learning in PE practice. With a point of departure in Crum's (1993) notion of movement cultures, the authors use video data from $30 \mathrm{PE}$ lessons in Sweden to study the different practices, norms and values that unfold. In the paper, they also discuss the different meanings of the cultures in terms of what the teachers and students strive to accomplish and the methodological principles involved in the lessons.

Following this, Gavin Ward and Mikael Quennerstedt (2015) explore how pupils and teachers constitute being-a-pupil and being-a-teacher in the primary school PE movement culture in the UK. Using John Dewey's theory of transaction, they study how pupils and teachers negotiate the movement culture. Their findings suggest that if $\mathrm{PE}$ is to be more than just the reproduction of codified sport, careful adjustment and consideration of ends-in-view are of great importance.

This is followed by Dean Barker and colleagues (2015), who aim to contribute to current theorising by examining social interactions in PE practice in terms of how inter-student interactions occur in a multimodal sense. The study takes its departure in symbolic interactionist theory and explores ongoing PE practices in Sweden with a view to understanding group work as an embodied practice involving particular epistemic ecologies, epistemic positions and learning trajectories.

In the fourth paper, Petter Leirhaug and Ann MacPhail (2015) explore assessment for learning (AfL) in Norwegian PE. In their study, AfL is explored in relation to how it is motivated, understood and enacted by PE teachers, and the extent to which such enactment complements or challenges the learning movement cultures in PE in Norway.

Following this, Chantal Amade-Escot and colleagues (2015) from France and Tunisia focus on gendered student learning in Tunisian PE. With a point of departure in Joint Action Studies in Didactics, the study sheds light on the intertwined processes of classroom interactions that influence the co-construction of gendered learning. In this way, the study explores the interplay between the teacher's practical epistemology and the students' gender positioning and how these affect inequalities in terms of students' learning and the maintenance of gender order in the gym.

Based on a sociocultural perspective on learning, the paper by Karin Redelius and colleagues (2015) examines how aims and learning goals are communicated in PE practice. They scrutinise how different teaching practices in Sweden are framed in terms of whether and how the aims and learning goals are made explicit or not to students in relation to different movement cultures.

Finally, Richard Tinning (2015) offers a commentary on all the papers in the special issue, where he in relation to the articles argues that progress towards a mature field of knowledge will require comparisons between sociocultural, behaviourist and cognitivist research on learning in PE. He argues that:

building our knowledge of learning in PE by means of sophisticated theorizing, rigorous empirical work [...], together with a process of vertical or compatible integration between research traditions, will contribute to the development of an understanding of learning that eventually might justifiably claim to be mature (p. 13). 


\section{References}

Amade-Escot, C., Elandoulsi, S., \& Verscheure, I. (2015). Physical education in Tunisia: Teachers' practical epistemology, students' positioning and gender issues. Sport, Education and Society. Advance online publication. doi:10.1080/13573322.2014.997694

Andersson, J., Östman, L., \& Öhman, M. (2013). I am sailing-towards a transactional analysis of 'body techniques'. Sport, Education and Society. Advance online publicatiion. doi:10.1080/ 13573322.2013 .802684

Ayvazo, S., Ward, P., \& Stuhr, P. T. (2010). Teaching and assessing content knowledge in preservice physical education. Fournal of Physical Education, Recreation E Dance, 81(4), 40-44. doi:10.1080/07303084.2010.10598463

Backman, E. (2008). What is valued in friluftsliv within PE teacher education?-Swedish PE teacher educators' thoughts about friluftsliv analysed through the perspective of Pierre Bourdieu. Sport, Education and Society, 13, 61-76.

Barker, D., Quennerstedt, M., \& Annerstedt, C. (2015). Learning through group work in physical education: A symbolic interactionist approach, Sport, Education and Society. Advance online publication. doi:10.1080/13573322.2014.962493

Burman, A., \& Sundgren, P. (2010). Bildning. Texter från Esaias Tegnér till Sven-Eric Liedman. [Buildung: Texts from Essias Tegnér to Sven-Eric Liedman] Gothenburg: Daidalos.

Cliff, K. (2012). A sociocultural perspective as a curriculum change in health and physical education. Sport, Education and Society, 17, 293-311.

Comenius, J. A. (1657/1907). Didactica Magna. [The great didactic] London: Adam \& Charles Black.

Crum, B. J. (1993). Conventional thought and practice in physical education: Problems of teaching and implications for change. Quest, 45, 339-356. doi:10.1080/00336297.1993.10484092

Engström, L. M. (2008). Who is physically active? Cultural capital and sports participation from adolescence to middle age-A 38-year follow-up study. Physical Education and Sport Pedagogy, 13, 319-343.

Enright, E., Hill, J., Sandford, R., \& Gard, M. (2014). Looking beyond what's broken: Towards an appreciative research agenda for physical education and sport pedagogy. Sport, Education and Society, 19, 819-926.

Evans, J., Davies, B., \& Rich, E. (2009). The body made flesh: Embodied learning and the corporeal device. British fournal of Sociology of Education, 30, 391-406. doi:10.1080/ 01425690902954588

Evans, J., Rich, E., Davies, B., \& Allwood, R. (2008). Education, disordered eating and obesity discourse: Fat fabrications. London: Routledge.

Gard, M., \& Wright, J. (2005). The obesity epidemic: Science, morality and ideology. London: Routledge.

Goodyear, V. A., Casey, A., \& Kirk, D. (2014). Hiding behind the camera: Social learning within the cooperative learning model to engage girls in physical education. Sport, Education and Society, 19, 712-734.

Harcourt, D., \& Quennerstedt, A. (2014). Ethical guardrails when children participate in research: Risk and practice in Sweden and Australia. SAGE Open, 4(3), 1-8. doi:10.1177/ 2158244014543782

Hudson, B., \& Meyer, M. A. (Eds.). (2011). Beyond fragmentation: Didactics, learning and teaching in Europe. Leverkusen Opladen: Barbara Budrich.

Kirk, D. (2009). Physical education futures. London: Routledge.

Kirk, D. (2012). Sport education, critical pedagogy and learning theory: Toward an intrinsic justification for physical education and youth sport. Quest, 58, 255-264. doi:10.1080/ 00336297.2006 .10491882 
Larsson, H., \& Karlefors, I. (2015). Physical education cultures in Sweden: Fitness, sports, dancing ... learning? Sport, Education and Society. Advance online publication. doi:10.1080/ 13573322.2014 .979143

Larsson, H., \& Redelius, K. (2008). Swedish physical education research questioned-current situation and future directions. Physical Education and Sport Pedagogy, 13, 381-398. doi: $10.1080 / 17408980802353354$

Leirhaug, P., \& MacPhail, A. (2015). 'It's the other assessment that is the key': Three Norwegian physical education teachers' engagement (or not) with assessment for learning. Sport, Education and Society. Advance online publication. doi:10.1080/13573322.2014.975113

Ljunggren, J. (2000). The masculine road through modernity. Ling gymnastics and male socialization in nineteenth-century Sweden. European Sports History Review, 2, 86-111.

MacPhail, A., Kirk, D., \& Kinchin, G. (2004). Sport education: Promoting team affiliation through physical education. Fournal of Teaching in Physical Education, 23(2), 106-122.

Maivorsdotter, N., \& Wickman, P. O. (2011). Skating in a life context: Examining the significance of aesthetic experience in sport using practical epistemology analysis. Sport, Education and Society, 16, 613-628.

McCaughtry, N. (2004). The emotional dimensions of a teacher's pedagogical content knowledge: Influences on content, curriculum, and pedagogy. Fournal of Teaching in Physical Education, 23(1), 30-47.

Oliver, K. L., \& Kirk, D. (2014). Towards an activist approach to research and advocacy for girls and physical education. Physical Education and Sport Pedagogy. Advance online publication. doi:10.1080/17408989.2014.895803

Pühse, U., \& Gerber, M. (Eds.). (2005). International comparison of physical education: Concepts, problems, prospects. Oxford: Meyer \& Meyer Sport.

Quennerstedt, M., Annerstedt, C., Barker, D., Karlefors, I., Larsson, H., Redelius, K., \& Öhman, M. (2014). What did they learn in school today? A method for exploring aspects of learning in physical education. European Physical Education Review, 20, 282-302. doi:10.1177/ $1356336 \mathrm{X} 14524864$

Quennerstedt, M., Öhman, M., \& Armour, K. (2014). Sport and exercise pedagogy and questions about learning. Sport, Education and Society, 19, 885-898.

Redelius, K., Quennerstedt, M., \& Öhman, M. (2015). Communicating aims and learning goals in physical education: Part of a subject for learning? Sport, Education and Society. Advance online publication. doi:10.1080/13573322.2014.987745

Rovegno, I. (1995). Theoretical perspectives on knowledge and learning and a student teacher's pedagogical content knowledge of dividing and sequencing subject matter. Fournal of Teaching in Physical Education, 14, 284-304.

Stirrup, J., \& Damant, E. (2014). Critical pedagogy, physical education and urban schooling. Sport, Education and Society, 19, 687-689.

Strandbu, Å., \& Steen-Johnsen, K. (2014). Bourdieu knew more than how to play tennis! An empirically based discussion of habituation and reflexivity. Sport, Education and Society, 19, 1055-1071.

Tinning, R. (2015). Commentary on research into learning in physical education: Towards a mature field of knowledge. Sport, Education and Society. Advance online publication. doi:10.1080/13573322.2014.994491.

Ward, G., \& Quennerstedt, M. (2015). Knowing in primary physical education in the UK: Negotiating movement culture. Sport, Education and Society. Advance online publication. doi:10.1080/13573322.2014.975114

Wertsch, J. V. (1998). Mind as action. Oxford: Oxford University Press. 